This work is licensed under Creative Commons Attribution 4.0 International (CC BY 4.0). [http://creativecommons.org/licenses/by/4.0/]

\title{
Milczące załatwienie sprawy w świetle zasady czynnego udziału strony postępowania administracyjnego - analiza teoretycznoprawna
}

Paula Konopczyńska | Uniwersytet Gdański https://orcid.org/0000-0003-2714-6299

Słowa kluczowe:

zasada czynnego udziału strony, milczące załatwienie sprawy, postępowanie administracyjne, strona

postępowania administracyjnego, ochrona praw strony

the principle of active participation

of the parties, the tacit settlement of the matter,

administrative proceedings, the party of the administrative proceedings, protection of the rights of the parties

\section{Streszczenie}

Celem niniejszego artykułu jest podjęcie próby analizy teoretycznoprawnej relacji zachodzącej pomiędzy wprowadzoną przez ustawodawcę konstrukcją materialnoprawną milczącego załatwienia sprawy a zasadą czynnego udziału strony, funkcjonującą w postępowaniu administracyjnym. Wspomniana konstrukcja materialnoprawna, jak również instytucja procesowa w postaci zasady czynnego udziału strony, są nośnikami pewnych gwarancji procesowych dla stron postępowania. Pomimo że są one różne treściowo, ich cele zdają się być zbieżne - milczące załatwienie sprawy oraz zasada czynnego udziału w dużej mierze służą protekcji praw stron. Tym samym nie można stwierdzić, iż pozostają one względem siebie w stosunku obojętności. Właśnie ze względu na ten fakt, jak również z uwagi na przewidziane przez ustawodawcę wyłączenia, dokonanie analizy teoretycznoprawnej jawi się jako pożądane.

The tacit settlement of the matter in the light of the principle of active participation of the parties in the administrative proceedings - theoretical and legal analysis (Summary)

The aim of the article is to make an attempt at theoretical and legal analysis of the relations between the tacit settlement of the matter adopted by the polish legislature and the principle of active participation of the parties in the administrative proceedings. Both the tacit settlement of the matter and the principle mentioned above are the carriers of procedural guarantees. Despite the fact that they have a different content, their purposes seem to be convergent because both of them serve to protect the rights of the parties. In particular, it cannot be claimed that they stay in the relation of indifference. Due to this and because of the exclusions imposed by the legislature, such analysis seems to be desirable. 


\section{Wstęp}

W rozdziale 8a ustawy z dnia 14 czerwca 1960 roku - Kodeks postępowania administracyjnego (dalej jako k.p.a.) uregulowana została instytucja milczącego załatwienia sprawy. Jej uwzględnienie w obecnie obowiązującej regulacji prawnej jest efektem nowelizacji dokonanej ustawą z dnia 7 kwietnia 2017 roku o zmianie ustawy - Kodeks postępowania administracyjnego oraz niektórych innych ustaw, która weszła w życie z dniem 1 czerwca 2017 roku. W niniejszym artykule postaram się ukazać zależność pomiędzy wprowadzoną przez ustawodawcę instytucją milczącego załatwienia sprawy a fundamentalną dla nauki prawa administracyjnego zasadą czynnego udziału strony. Zasada ta, wyrażona w art. 10 k.p.a. i funkcjonująca w postępowaniu administracyjnym, ma szczególnie doniosły charakter. To właśnie ze względu na jej wysoką rangę przedmiotowy temat niewątpliwie wymaga analizy teoretycznoprawnej.

\section{Zgodnie z literą prawa}

Aby zrozumieć zależność obu wspomnianych instytucji, w pierwszej kolejności należy odnieść się do treści k.p.a. Zgodnie z art. 122a k.p.a. istotą milczącego załatwienia sprawy jest umożliwienie uznania sprawy za załatwioną milcząco, gdy w przepisanym ustawowo terminie (tj. w terminie miesiąca od doręczenia żądania strony lub w innym przewidzianym w przepisach szczególnych terminie) organ administracji publicznej nie wyda decyzji lub postanowienia kończącego postępowanie w sprawie (art. 122a $\S 2$ ust. 1 k.p.a.) albo nie wniesie sprzeciwu w drodze decyzji (art. 122a § 1 ust. 2 k.p.a.). W takiej sytuacji sprawa załatwiana jest w sposób w całości uwzględniający żądanie strony. Przywołany artykuł nie stanowi jednocześnie dyspozycji do każdorazowego załatwiania spraw w sposób milczący. Słusznie wskazał Piotr Marek Przybysz, iż powołany przepis nie jest samoistną podstawą do takiego postępowania w przypadku braku adekwatnej reakcji ze strony organu. Możliwość załatwienia sprawy milcząco występuje jedynie wówczas, gdy stanowi tak przepis szczególny (Przybysz 2019).

Od milczącego załatwienia sprawy należy odróżniać bezczynność organu, na co trafnie zwrócił uwagę Wojciech Sawczyn. Autor ten podkreślił, iż w prawie administracyjnym oba wskazane pojęcia nie mogą być pojmowane jako synonimiczne, bowiem milczące załatwienie sprawy stanowi odrębną konstrukcję prawną (Sawczyn 2019: 207). Słusznie zauważył to także Michał Miłosz, wskazując, iż milczące załatwienie sprawy (w odróżnieniu od bezczynności organu) nie jest działaniem bezprawnym, a instytucją prawną przewidzianą przez ustawodawcę. W przypadku milczącego załatwienia sprawy to konkretna norma kompetencyjna daje organowi możliwość biernego działania w pewnym spektrum sytuacji (Miłosz 2016: 106-108).

Głównym skutkiem milczenia organu administracji publicznej jest nabycie przez podmiot wnoszący żądania uprawnienia administracyjnego, co czyni opisywaną instytucję specyficzną metodą urzeczywistniającą normy prawa administracyjnego (Miłosz 
2016: 106). Zdaniem Sawczyna milczące załatwienie sprawy może przybierać dwie formy: aktywną - w postaci milczącej zgody - oraz pasywną - w postaci milczącego załatwienia postępowania (Sawczyn 2019: 208). Istotą pierwszej z form jest uzyskanie przez podmiot występujący z żądaniem tzw. milczącej zgody, a więc aprobaty od organu administracji publicznej co do wskazanego w żądaniu jednostki sposobu załatwienia sprawy, co niewątpliwie może służyć usprawnieniu procedury. Celem drugiej z nich jest przyczynienie się do załatwienia sprawy przez organ administracji publicznej w przewidzianym ustawowo terminie, a więc poniekąd zmobilizowanie tego organu do właściwego działania (Sawczyn 2019: 208-209). Warto jednak mieć na względzie fakt, na który zwrócił już uwagę Marcin Kamiński, a mianowicie, iż wprowadzone przez ustawodawcę przepisy rozdziału 8a k.p.a. (tj. przepisy regulujące milczące załatwienie sprawy) mają zastosowanie wówczas, gdy jest to przewidziane przez prawo materialne. Tym samym w pierwszej kolejności należy stosować szczególne przepisy prawa materialnego, regulujące tryb milczącego załatwienia sprawy, a dopiero w braku szczególnej regulacji posiłkować się odpowiednio przepisami k.p.a. (Kamiński 2019: 45-46). Kamiński zwrócił również uwagę na to, że milczenie administracji służy różnym celom, i tak oto w sferze materialnoprawnej wywołuje skutki prawne określone przez podmiot wnoszący podanie, przyznaje uprawnienia, znosi obowiązki, przeciwdziała bezczynności organów oraz przewlekłości postępowań, a nadto służy ich przyśpieszeniu lub uproszczeniu (Kamiński 2019: 48-49). Na tę okoliczność wspomniany autor przytacza szereg przepisów prawnych, w tym między innymi art. 30 ust. 5 ustawy z dnia 7 lipca 1994 roku - Prawo budowlane (dalej jako p.b.), mówiący o możliwości przystąpienia do robót budowlanych w przypadku braku zgłoszenia przez organ administracji architektoniczno-budowlanej sprzeciwu w terminie 21 dni od dnia doręczenia zgłoszenia (Kamiński 2019: 49). Na marginesie warto nadmienić, że Wojewódzki Sąd Administracyjny w Opolu w wyroku z dnia 14 lipca 2016 roku (II SA/Op 155/16), oceniając charakter zgłoszenia wskazanego w art. 60 ust. 5 p.b., uznał, iż nie jest ono standardową formą wniosku (podania) z art. 61 k.p.a., a jedynie oświadczeniem woli inwestora, zaś przyjęcie tego oświadczenia przez organ administracji publicznej w sposób milczący stanowi czynność materialno-techniczną. Niemniej jednak jest to jeden z wielu przykładów milczącego załatwienia sprawy. Należy jednocześnie zwrócić uwagę na to, co wskazał już Marek Szewczyk, a mianowicie fakt, iż w polskim ustawodawstwie milczące załatwienie sprawy istnieje od lat, jednakże jego implementacja do k.p.a. nastąpiła dopiero wraz z wyżej wspomnianą nowelizacją (Szewczyk 2019: 272-273).

Omawiając powyższą konstrukcję materialnoprawną, warto mieć na względzie to, jak jej wprowadzenie rzutuje na pozostałe, fundamentalne instytucje procedury administracyjnej. Jedną z nich jest zasada czynnego udziału strony, wyrażona w art. 10 k.p.a. Zgodnie z $§ 1$ wymienionego artykułu "organy administracji publicznej obowiązane są zapewnić stronom czynny udział w każdym stadium postępowania, a przed wydaniem decyzji umożliwić im wypowiedzenie się co do zebranych dowodów i materiałów oraz zgłoszonych żądań". Tym samym obowiązkiem organów jest każdorazowe zapewnienie stronom postępowania administracyjnego możliwości udziału w każdym stadium 
postępowania, jak również odniesienia się do zebranego w sprawie materiału dowodowego. Przywołany przepis w $\S 2$ przewiduje możliwość odstąpienia przez organy administracji publicznej od wyżej wymienionej zasady, w przypadku gdy „załatwienie sprawy nie cierpi zwłoki ze względu na niebezpieczeństwo dla życia lub zdrowia ludzkiego albo ze względu na grożącą niepowetowaną szkodę materialną". Oznacza to, iż ustawodawca przewidział pewien katalog sytuacji, w których pominięcie zasady czynnego udziału strony uznawane jest za dopuszczalne. Jak się jednak okazało, zasada ta została wyłączona także w sprawach załatwianych milcząco, o czym poniżej.

\section{Milczące załatwienie sprawy a zasada czynnego udziału strony}

Powracając do instytucji milczącego załatwienia sprawy, należy zwrócić szczególną uwagę na art. 122d § 1 k.p.a., zgodnie z którym „do spraw załatwianych milcząco nie stosuje się art. 10 k.p.a... Powyższe oznacza, iż w przypadku milczącego załatwiania sprawy zasada czynnego udziału strony podlega wyłączeniu. Przyjęte rozwiązanie zostało wyjaśnione w projekcie ustawy, na co zwrócił uwagę Sawczyn (2017: 216). Zgodnie z uzasadnieniem projektu w sprawach załatwianych milcząco zastosowanie zasady czynnego udziału strony w postępowaniu administracyjnym nie jest wymagane ze względu na uproszczony charakter przedmiotowego trybu. $Z$ treści uzasadnienia wynika także, że w sprawie załatwianej milcząco rozstrzygnięcie wydawane jest w oparciu o materiał, który strony przedstawią na etapie wszczęcia postępowania, natomiast sprawy rozpoznawane we wskazanym trybie powinny odznaczać się niewielkim stopniem skomplikowania (zob. uzasadnienie rządowego projektu ustawy o zmianie ustawy - Kodeks postępowania administracyjnego oraz niektórych ustaw, druk nr 1183, s. 39). W opinii Kancelarii Senatu odnoszącej się do opisywanej nowelizacji wskazano nadto, że ustawodawca dążył do tego, aby stworzyć dwa różne modele postępowania. Tym samym z milczącym zakończeniem postępowania należy łączyć przeciwdziałanie bezczynności organu administracji, bowiem w przypadku spraw kończących się milcząco pożądanym działaniem organu co do zasady powinno być wydanie decyzji administracyjnej. Z kolei milcząca zgoda służy uproszczeniu postępowania, gdyż niewniesienie przez organ administracji publicznej sprzeciwu umożliwia rozwiązanie sprawy w ten właśnie sposób (zob. opinia Kancelarii Senatu, Biura Legislacyjnego do ustawy o zmianie ustawy - Kodeks postępowania administracyjnego oraz niektórych ustaw, druk nr 439). Warto przy tym zauważyć, iż zdaniem autorów opisywanej nowelizacji celem wprowadzenia instytucji milczącego załatwienia sprawy było „przyśpieszenie i uproszczenie postępowania administracyjnego, jak również usprawnienie i zmniejszenie kosztów funkcjonowania administracji" (zob. uzasadnienie rządowego projektu ustawy o zmianie ustawy - Kodeks postępowania administracyjnego oraz niektórych ustaw, druk nr 1183, s. 45). Z przywołanego uzasadnienia wynika również, iż w latach bezpośrednio poprzedzających wprowadzenie nowelizacji (tj. w latach 2015-2016) do wojewódzkich sądów administracyjnych wpłynęło wiele skarg na bezczynność organów administracji publicznej lub też na przewlekłe 
prowadzenie postępowań administracyjnych. Powyższe wiązało się z obciążaniem organów administracji publicznej grzywnami, a przede wszystkim znacznym przedłużaniem prowadzonych przez nie postępowań (s. 3 uzasadnienia).

O ile wymienione przesłanki zdają się być dostatecznie racjonalne, o tyle całkowite wyłączenie zasady czynnego udziały strony w przypadku spraw załatwianych milcząco jest już kwestią sporną. Skoro zgodnie z art. 1 § 1 k.p.a. instytucja milczącego załatwienia sprawy funkcjonuje w postępowaniu administracyjnym, to wyłączenie $z$ tego postępowania wspomnianej zasady rodzi poważne wątpliwości. Wszak przedmiotem rozpoznania jest żądanie strony, którego to uwzględnienie w rzeczywistości zmieni jej sytuację administracyjnoprawną. Co prawda oczywiste jest, że strona, wnosząc żądanie, przede wszystkim oczekuje jego uwzględnienia, jednak niekiedy to właśnie podjęcie dodatkowych czynności w postępowaniu (np. w postaci uzupełnienia materiału dowodowego) ma istotny wpływ na treść wydawanego rozstrzygnięcia. W tym zaś kontekście istotne zdaje się być to, czy gdyby takie czynności zostały podjęte, treść opisywanego rozstrzygnięcia uległaby zmianie, a jeśli tak, to w jaki sposób. Krzysztof Sobieralski słusznie zauważył, że milczące załatwienie sprawy może oznaczać zarówno sytuacje, w których organ administracji publicznej celowo nie podejmuje czynności w przewidzianym ustawowo terminie, jak również sytuacje, w których czynności nie są podejmowane przez organ w sposób nieświadomy. Warto jednocześnie zauważyć, że celowe niepodjęcie wymaganej czynności może być spowodowane uprzednim podjęciem przez organ administracji publicznej szeregu innych czynności sprawdzających, a w efekcie dojściem do wniosku, że brak jest przeszkód dla pozytywnego rozpatrzenia żądania strony (Sobieralski 2018:452). Na powyższe zwrócił uwagę także Kamiński, wskazując, iż niezależnie od tego, czy zaniechanie prawne organu jest zamierzone, czy też jest oparte na przyczynach obiektywnych, to nadal wiąże się z konsekwencjami prawnymi w postaci nabycia uprawnienia lub też powstania stanu fikcji prawnej (Kamiński 2019: 48). Tym samym wpływ opisywanego trybu na sytuację administracyjnoprawną jednostki jest niewątpliwy.

W tym miejscu na przytoczenie zasługuje stanowisko Ewy Szewczyk oraz Marka Szewczyka, zgodnie z którym założenie przyjęte przez twórców ostatecznej wersji nowelizacji k.p.a. jakoby w sprawach załatwianych milcząco jedynym podmiotem występującym w charakterze strony byłby ten wnoszący podanie, jest błędne. Wspomniani autorzy za wyraz takiego założenia uznali między innymi treść art. $122 \mathrm{~d} \S 1$ k.p.a. obok art. 122c 11 zd. 2 k.p.a. (Szewczyk, Szewczyk 2018: 290). Jednocześnie zwrócili uwagę na to, iż pozostaje z nim w sprzeczności treść art. 122d § 4 k.p.a., zgodnie z którym zaświadczenie o milczącym załatwieniu sprawy doręczane jest wszystkim stronom postępowania. To z kolei świadczyłoby o tym, że założeniem racjonalnego ustawodawcy nie było uznanie za jedyną stronę postępowania tylko podmiotu wnoszącego podanie. Zdaniem wymienionych autorów dotychczasowa linia orzecznicza była chybiona (Szewczyk, Szewczyk 2018: 291). 
W dalszej części wskazać należy, że zgodnie ze stanowiskiem Magdaleny Sieniuć prawo do czynnego udziału strony w postępowaniu administracyjnym jest równoznaczne $z$ prawem strony do uczestnictwa $w$ danym postępowaniu, począwszy "od momentu jego wszczęcia aż po jego zakończenie w drodze decyzji administracyjnej" (Sieniuć 2018: 383). Tymczasem w przypadku milczącego załatwienia sprawy uprawnienia strony zdają się być ograniczone. Przede wszystkim należy zauważyć, że zgodnie z art. 122e k.p.a. w aktach sprawy organ administracji publicznej zamieszcza adnotację o milczącym załatwieniu sprawy ze wskazaniem treści rozstrzygnięcia oraz podstawy prawnej. Natomiast zgodnie z art. $122 \mathrm{f} \S 1$ k.p.a. ten sam organ na wniosek strony w drodze postanowienia wydaje lub też odmawia wydania stronie zaświadczenia o milczącym załatwieniu konkretnej sprawy. Postanowienie to wywołuje skutki materialnoprawne (ustala treść rozstrzygnięcia i o nim zaświadcza) oraz odznacza się charakterem deklaratoryjnym (Szewczyk 2019: 281). Co więcej, zgodnie z art. $122 f \S 2$ k.p.a. na wydane postanowienie przysługuje zażalenie. Za ciekawe należy uznać także to, że elementy wymienionego zaświadczenia łudząco przypominają elementy decyzji administracyjnej, choć brak jest w nim uzasadnienia (Szewczyk 2019: 282). Ten fakt również stwarza ryzyko w zakresie ochrony praw stron postępowania, szczególnie wówczas, gdy w sprawie występuje więcej stron o różnych interesach prawnych. Zauważył to Marek Szewczyk, nawiązując do realizacji inwestycji budowlanych w postaci między innymi inwestycji celu publicznego (Szewczyk 2019: 282-283).

Odnosząc się ponownie do kwestii zaświadczenia wydawanego w sprawach załatwianych milcząco, nadmienić należy, iż organ może, ale nie musi, wydać stronie zaświadczenie, natomiast strona (zgodnie z art. $122 f$ § 2 k.p.a.) może wnieść zażalenie na wydane przez organ postanowienie. W tym przypadku stwierdzenie „na wniosek strony" powinno być pojmowane w odniesieniu do całej regulacji k.p.a., w szczególności przy uwzględnieniu treści art. 28 k.p.a. (Szewczyk 2019: 275). Brak jest zatem podstaw do zawężania kręgu stron jedynie do podmiotu wnoszącego podanie, skoro katalog stron powinien być badany zgodnie z treścią art. 28 k.p.a. Przywołany artykuł stanowi bowiem, że status strony przysługuje każdemu, czyjego interesu prawnego lub też obowiązku dotyczy prowadzone postępowanie lub też temu, kto z uwagi na wspomniany interes prawny lub obowiązek żąda czynności konkretnego organu. Domniemywać można zatem, że stronami postępowania w sprawach załatwianych milcząco mogłaby być większa grupa ludzi niźli jedynie sam podmiot wnoszący podanie.

Powracając jednak do wspomnianego środka zaskarżenia, warto wspomnieć, że w drodze przedmiotowego zażalenia stronom przysługuje jedynie prawo żądania formalnej weryfikacji w zakresie prawidłowości wydania lub odmowy wydania postanowienia, natomiast poza zakresem żądania stron pozostaje weryfikacja materialnoprawna sprawy. Ponadto dysponują one prawem do żądania wznowienia postępowania w sprawie lub też wniesienia o stwierdzenie nieważności wydanego postanowienia w oparciu o art. 126 k.p.a. w związku z art. 122f § 2 k.p.a. (Kamiński 2019: 56). Z powyższego można zatem wywnioskować, iż czynny udział strony niebędącej wnioskodawcą podlega 
niejako ograniczeniu, ponieważ strona ta może włączyć się do sprawy dopiero po jej załatwieniu w sposób milczący. Przewidziane przez ustawodawcę ograniczenia (w tym także wyłączenie weryfikacji sprawy załatwianej milcząco w postępowaniu odwoławczym) służą jednocześnie uproszczeniu oraz przyśpieszeniu procedury, a także przeciwdziałaniu bezczynności organów administracji publicznej (Kamiński 2019: 57). Wprowadzenie instytucji, które prowadziłyby do osłabienia lub nawet podważenia konstrukcji milczącego załatwienia sprawy, przeczyłoby założeniom ustawodawcy (Kamiński 2019: 57). Z drugiej jednak strony nasuwa się pytanie, czy strona (lub też strony) będą miały szansę powzięcia informacji o sposobie załatwienia ich sprawy. Słusznie wskazało Samorządowe Kolegium Odwoławcze w Gdańsku w swojej decyzji z dnia 16 marca 2011 roku (3509/10), stwierdzając, że warunkiem aktywnego uczestnictwa strony w postępowaniu jest jej świadomość, że postępowanie się toczy. Skoro zaś wydanie zaświadczenia o milczącym załatwieniu sprawy następuje na wniosek, strona powinna być w pełni świadoma możliwości złożenia takiego wniosku, a zatem mieć wiedzę o toczącym się postępowaniu. Niezależnie jednak od powyższego ustawodawca w art. $122 f \S 4$ k.p.a. przewidział możliwość poinformowania stron o wydanym zaświadczeniu, a tym samym umożliwienia im udziału w nadzwyczajnym trybie postępowania.

\section{W świetle wątpliwości}

Podejmując próbę analizy teoretycznoprawnej milczącego załatwienia sprawy, nie sposób uniknąć wątpliwości nasuwających się w toku tej analizy. Z pewnością celem wprowadzonej konstrukcji jest realizacja zasady szybkości postępowania, wyrażonej w art. 12 k.p.a., jednakże na względzie należy mieć fakt, iż nie jest ona zasadą nadrzędną względem pozostałych zasad k.p.a. Przykładowo wskazać w tym miejscu należy pogląd Piotra Kobylskiego, który analizując nowelizację procedury administracyjnej, we wstępie swoich rozważań podkreślił, że zasada szybkości postępowania nie ma prymatu nad zasadą prawdy obiektywnej, bo wszelkie czynności organów administracji powinny być staranne i odznaczać się wnikliwością, zaś w gestii organu jest ustalenie wszelkich okoliczności mających wpływ na wydane orzeczenie (Kobylski 2018: 150). Wspomniany autor w dalszej części wskazał, że szybkość postępowania nie może także naruszać prawa strony do czynnego udziału w postępowaniu (Kobylski 2018: 150). Jego zdaniem sama forma postępowania w sprawach załatwianych milcząco w sposób istotny narusza zasadę z art. 10 k.p.a., czego powodem jest między innymi ograniczenie postępowania dowodowego do dokumentacji oraz wniosków wskazanych przez stronę w żądaniu, jak również dokumentacji dostępnej organowi, a także brak możliwości realizacji uprawnień w postępowaniu odwoławczym (Kobylski 2018: 155). Pogląd dotyczący braku prymatu zasady szybkości nad innymi zasadami postępowania administracyjnego podzieliła także Joanna Człowiekowska (2019: 323). Warto jednak zauważyć, że zarówno zasada szybkości postępowania administracyjnego, jak i zasada czynnego udziału strony w postępowaniu administracyjnym znajdują 
swoje odzwierciedlenie w zaleceniach (standardach) o randze międzynarodowej (przykładowo: art. 16 oraz art. 17 Europejskiego Kodeksu Dobrej Praktyki Administracyjnej zatwierdzonego przez Parlament Europejski w dniu 6 września 2001 roku, wersja z dnia 1 marca 2002 roku). Skoro zaś zasada szybkości postępowania nie zajmuje nadrzędnej pozycji względem pozostałych zasad regulujących postępowanie administracyjne, to tym bardziej zastanowienia wymaga to, dlaczego powinna ograniczać jedną z fundamentalnych zasad procesowych, tj. zasadę z art. 10 k.p.a. Z drugiej zaś strony, skoro tryb milczącego załatwienia sprawy powinien regulować procedury nieskomplikowane, to czy ich wydłużenie (a w istocie komplikowanie) nie zrówna wskazanego trybu ze standardowym postępowaniem administracyjnym, a tym samym instytucja milczącego załatwienia sprawy nie spełni przyświecających jej celów? Zbigniew Kmieciak, pisząc o gwarancjach procesowych jednostki w postępowaniu administracyjnym, odniósł się do takich czynników, jak efektywność, koszty oraz sprawny przebieg postępowania, podkreślając jednocześnie, że wzmacnianie pozycji procesowej stron postępowania administracyjnego w oderwaniu od tych czynników nie znajduje silnego uzasadnienia, a wręcz zamiast służyć ochronie interesu indywidualnego prowadzi do komplikowania przyjętych rozwiązań (Kmieciak 2014: 186-187). Wspomniany autor przychylił się również do konieczności modernizacji postępowania administracyjnego, a przez to rezygnacji z niektórych przysługujących stronie praw celem usprawnienia procedury oraz jej efektywności, jak również minimalizacji kosztów. Rezygnacja ta powinna jednak następować bez uszczerbku dla stron postępowania (Kmieciak 2014: 196). Nie sposób nie zgodzić się z taką koncepcją, zgodnie z którą procedury odznaczające się niskim stopniem skomplikowania nie powinny być nadmiernie utrudniane. Jednakże istotne jest to, co przesądza o stopniu skomplikowania danej procedury. $Z$ kolei zdaniem Sobieralskiego wyłączenie zasady $z$ art. 10 k.p.a. w sprawach załatwianych milcząco jest rozwiązaniem logicznym, jako że strona dąży do uzyskania uprawnienia, zaś w przypadku wystąpienia skutku z art. 122a k.p.a. pozbawienie strony uprawnień wynikających z zasady czynnego udziału strony w istocie nie ma znaczenia (Sobieralski 2018: 455). Podkreślił on także, że sama konieczność dokonania wszelkich czynności wynikających z art. 10 k.p.a. przed wydaniem aktu spowodowałaby uchybienie terminowi wskazanemu w ustawie, natomiast przyjęte przez ustawodawcę rozwiązanie dotyczące wyłączenia zasady czynnego udziału strony w trybie zwykłym nie prowadzi do naruszenia interesu pozostałych stron postępowania, bowiem mają one możliwość skorzystania z trybów nadzwyczajnych. Jest to jednocześnie możliwość obalenia skutku materialnego milczącego załatwienia sprawy (Sobieralski 2018: 455-456). W swoim podsumowaniu autor ten stwierdza, że sposób regulacji trybu milczącego załatwienia sprawy umożliwił przyjęcie jednakowego postępowania we wszystkich sprawach, w przypadku których prawo materialne przewiduje możliwość milczącego załatwienia sprawy, a tym samym regulacja ta „zasługuje na pozytywną ocenę" (Sobieralski 2018: 458). 


\section{Zakończenie}

W mojej ocenie postępowania w sprawach załatwianych milcząco, jako szczególne postępowania uproszczone, powinny odznaczać się uniwersalnym i nieskomplikowanym charakterem, który pozwoliłby na przyjęcie rozwiązania w postaci milczącego załatwiania sprawy bez ryzyka pokrzywdzenia praw stron postępowania. Michał Miłosz słusznie zauważył, że instytucja prawna milczenia może w rzeczywistości służyć eliminowaniu zjawiska bezczynności organu, jednak między innymi ze względu na ryzyko występowania naruszeń indywidualnych interesów jednostek konieczne byłoby zagwarantowanie instrumentów służących ich ochronie (Miłosz 2011: 252). Wszak gwarancje procesowe są traktowane jako „oczywiste i powszechnie zrozumiałe" (Kmieciak 2014: 187). Tym samym ich ograniczenia są zjawiskiem niepożądanym, przy czym za wyjątek uznać należałoby takie sprawy, w których pomimo dokonania wyłączeń ryzyko naruszenia praw stron nie występuje. Nawet znikomy stopień wystąpienia ryzyka powinien uniemożliwić wprowadzenie opisywanych ograniczeń. W istocie to właśnie gwarancje procesowe wyposażają stronę w narzędzia służące ochronie jej praw, a również w interesie organu administracji publicznej jest załatwienie sprawy w sposób niewymagający uruchomiana dalszych trybów postępowania. Skądinąd rzeczywista ocena skutków wyłączeń wprowadzonych wraz z instytucją milczącego załatwienia sprawy na obecnym etapie zdaje się być niemożliwa.

\section{Bibliografia}

Człowiekowska J., 2019, Materialnoprawne aspekty milczącego załatwienia sprawy w świetle instytucji prawa budowlanego [w:] Z. Kmieciak, M. Gajda-Durlik (red.), Milczące załatwienie sprawy przez organ administracji publicznej, Warszawa.

Decyzja Samorządowego Kolegium Odwoławczego w Gdańsku z dnia 16 marca 2011 r., SKO/Gd 3509/10, LEX nr 1727535.

Europejski Kodeks Dobrej Praktyki Administracyjnej zatwierdzony przez Parlament Europejski w dniu 6 września 2001 r., wersja z dnia 1 marca 2002 r., https://www.ombudsman.europa.eu/pl/publication/pl/3510\#/page/1 [dostęp: 15.09.2019].

Kamiński M., 2019, Milczenie administracyjne a milczq̨ce załatwienie sprawy ijego weryfikacja. Rozwiqzania normatywne w prawie polskim na tle prawnoporównawczym [w:] Z. Kmieciak, M. Gajda-Durlik (red.), Milczące załatwienie sprawy przez organ administracji publicznej, Warszawa.

Kmieciak Z., 2014, Zarys teorii postępowania administracyjnego, Warszawa.

Kobylski P., 2018, Usprawnienie postępowania administracyjnego w świetle nowelizacji Kodeksu postępowania administracyjnego, ,Zeszyty Naukowe Towarzystwa Doktorantów Uniwersytetu Jagiellońskiego", Nauki Społeczne, Tom Prawniczy, nr 21.

Miłosz M., 2011, Bezczynność organu administracji publicznej w postępowaniu administracyjnym, Warszawa.

Miłosz M., 2016, Milczenie organu administracji publicznej [w:] T. Bąkowski, K. Żukowski (red.), Leksykon prawa administracyjnego materialnego. 100 podstawowych pojęć, Warszawa. 
Opinia Kancelarii Senatu, Biura Legislacyjnego do ustawy o zmianie ustawy - Kodeks postępowania administracyjnego oraz niektórych ustaw, druk nr 439, https://www.senat.gov.pl/prace/senat/ posiedzenia/tematy-posiedzen-senatu-ix-kadencji/ [dostęp: 14.06.2019].

Przybysz P. M., 2019, Kodeks postępowania administracyjnego. Komentarz aktualizowany, LEX/el.

Rządowy projekt ustawy o zmianie ustawy - Kodeks postępowania administracyjnego oraz niektórych innych ustaw, druk nr 1183, http://www.sejm.gov.pl/Sejm8.nsf/druk.xsp?nr=1183 [dostęp: 15.09.2019].

Sawczyn W., 2019, Milczące załatwienie sprawy [w:] R. Hauser, Z. Niewiadomski, A. Wróbel (red.), System Prawa Administracyjnego. Prawo procesowe administracyjne, Warszawa.

Sieniuć M., 2018, Klasyfikacja zasad ogólnych postępowania administracyjnego [w:] G. Łaszczyca, A. Matan (red.), System Prawa Administracyjnego Procesowego. Zasady ogólne postępowania administracyjnego, Warszawa.

Sobieralski K., 2018, Milczenie jako prawna forma niedziałania administracji - konsekwencje procesowe [w:] Korczak J. (red.), Cywilizacja administracji publicznej. Księga Jubileuszowa z okazji 80-lecia urodzin prof. nadzw. UWr dra hab. Jana Jeżewskiego, Warszawa.

Szewczyk E., Szewczyk M., 2018, Strona w postępowaniu administracyjnym [w:] G. Łaszczyca, A. Matan (red.), System Prawa Administracyjnego Procesowego. Zakres przedmiotowy i podmiotowy postępowania administracyjnego ogólnego, Warszawa.

Szewczyk M., 2019, Zaświadczenie o milczącym załatwieniu sprawy a zaświadczenie z działu VII Kodeksu postępowania administracyjnego [w:] Z. Kmieciak, M. Gajda-Durlik (red.), Milczące załatwienie sprawy przez organ administracji publicznej, Warszawa.

Ustawa z dnia 14 czerwca 1960 r. - Kodeks postępowania administracyjnego (tekst jednolity: Dz. U. z 2018 r., poz. 2096), http://prawo.sejm.gov.pl/isap.nsf/DocDetails.xsp?id=WDU19600300168 [dostęp: 2.06.2019].

Ustawa z dnia 7 lipca 1994 r. - Prawo budowlane (tekst jednolity: Dz. U. z 2019 r., poz. 1186), http:// prawo.sejm.gov.pl/isap.nsf/DocDetails.xsp?id=WDU19940890414 [dostęp: 8.06.2019].

Ustawa z dnia 7 kwietnia 2017 r. o zmianie ustawy - Kodeks postępowania administracyjnego oraz niektórych innych ustaw (Dz. U. poz. 935), http://prawo.sejm.gov.pl/isap.nsf/DocDetails.xsp?id=WDU20170000935 [dostęp: 2.06.2019].

Wyrok Wojewódzkiego Sądu Administracyjnego w Opolu z dnia 14 lipca 2016 r., II SA/Op 155/16, http://orzeczenia.nsa.gov.pl/doc/BEBE201683 [dostęp: 15.06.2019].

\section{Biogram}

Paula Konopczyńska - absolwentka studiów magisterskich na kierunku Prawo na Uniwersytecie Gdańskim, doktorantka w zakresie prawa na wymienionej uczelni. W pracy naukowo-badawczej skupia się w szczególności na ogólnym postępowaniu administracyjnym, a dokładniej na udziale stron w tymże postępowaniu (z całym spektrum uprawnień i ograniczeń), co odzwierciedla jej aktualne zainteresowania badawcze. Dotychczas miała szansę współpracować z redakcją "Gazety Wydziału Prawa i Administracji Uniwersytetu Gdańskiego" oraz "Gdańskiego Kwartalnika Adwokackiego". Jest stypendystką programu PROM Narodowej Agencji Wymiany Akademickiej (Międzynarodowa wymiana stypendialna doktorantów i kadry akademickiej, 2019) oraz Zastępcą Rzecznika Praw Doktoranta i Przewodniczącą Zespołu Prawnego Rzecznika Praw Doktoranta Krajowej Reprezentacji Doktorantów (2019-2020). 